\title{
Is the military coup in Myanmar the death knell of democracy and federalism?
}

Edition 5, 2021

Dr Michael Breen and Dr Anne Décobert

DOI: 10.37839/MAR2652-550X5.15

When the Myanmar military (Tatmadaw) drove into the capital Naypyidaw in the early hours of 1 February 2021 to seize power, many were taken by surprise. The military had made lightly-veiled threats to this effect, but many within and beyond the country remained hopeful that they would not be carried through.

The coup has major potential consequences for a country that was struggling to emerge from decades of military oppression and conflict. It could crush further progress towards democracy and federalism, and lead to increased violence in ethnic States.

On 8 November 2020, Myanmar held its third election under its controversial 2008 Constitution. A victory by the governing party, the National League for Democracy (NLD) led by Daw Aung San Suu Kyi, was widely expected. But the extent of the overwhelming majority won by the NLD was not. The NLD's gains were key in instigating the military to seize control. The election and subsequent coup highlight major unresolved structural and political problems in Myanmar, and have significant implications for the future of democratisation, federalism and the peace process. 


\section{The 2020 elections: another NLD landslide victory}

Myanmar's 2008 Constitution, ostensibly drafted through a deliberative national convention, is in reality a creature of the military. It reserves for the military 25 percent of seats in each parliament at Central, State and Region levels, and it gives them control over three important ministerial portfolios-Defence, Home Affairs and Border Affairs. In other words, the military retains significant influence over governance, is not subject to civilian control and commands the state's security apparatus.

The 2008 Constitution also gives the military the right to intervene and take control in specific circumstances. This provision has been invoked by the military in its attempts to provide the coup and their reversal of Myanmar's fledgling democratisation with a veneer of legitimacy.

After boycotting the elections in 2010, the NLD won the 2015 elections with much fanfare. Its landslide victory heralded, many commentators believed, a new democratic era and the potential resolution of longstanding conflicts between the Bamar-dominated state and a variety of Ethnic Armed Organisations. Although the military-aligned Union Solidarity and Development Party (USDP), which won the 2010 election, had introduced many positive reforms and processes, the NLD was widely seen as the party that could best deliver on the people's aspirations for peace, democracy and federalism.

However, five years later, many members of ethnic nationality communities-and indeed, many democratic reformers-were deeply dissatisfied. Promises of federalism had not led to substantial reform. Conflict had continued in many ethnic areas, even restarting in some ceasefire areas. There had been crackdowns on freedom of speech and other democratic rights. And the NLD had defended the military against allegations of genocide and other human rights abuses against 
Rohingya people in Rakhine State.

Seemingly, none of this translated into a vote against the NLD in the November 2020 election. Its victory was even bigger than in 2015. Overall, it won more than 83 percent of elected seats, up from 79 percent in 2015, giving it 62 percent of seats in the Union Parliament (Pyidaungsu Hluttaw, see Table 1)[1]. This should have given it the power to form government and select the President of the Union, despite the military-reserved seats. The military-backed USDP performed badly, winning only seven percent of elected seats (five percent of the overall total)-a crushing blow for the military and its allies.

This was significant in instigating the coup. Although the military initially accepted the results, the USDP cast doubt on the outcome and threatened legal action. Soon the military joined, claiming widespread electoral fraud, despite the certification by the Union Election Commission and the endorsement of international observers. The NLD was aware of the risk of a coup, even reminding the military that a coup is illegal under the military's own 2008 Constitution.

\section{Table 1: Distribution of seats in the Union Parliament following the 2020 election}




\begin{tabular}{|l|c|c|c|}
\hline Party & Seats & $\begin{array}{c}\text { \% of } \\
\text { elected } \\
\text { seats }\end{array}$ & $\begin{array}{c}\text { \% of total } \\
\text { seats }\end{array}$ \\
\hline National League for Democracy & 396 & $\mathbf{8 3}$ & $\mathbf{6 2}$ \\
\hline Union Solidarity and Development Party & 33 & $\mathbf{7}$ & $\mathbf{5}$ \\
\hline Shan National League for Democracy & $\mathbf{1 5}$ & $\mathbf{3}$ & $\mathbf{2}$ \\
\hline Arakan National Party & $\mathbf{8}$ & $\mathbf{2}$ & $\mathbf{1}$ \\
\hline Ta'ang National Party & $\mathbf{5}$ & $\mathbf{1}$ & $<\mathbf{1}$ \\
\hline Pa'O National Organisation & $\mathbf{4}$ & $\mathbf{1}$ & $<\mathbf{1}$ \\
\hline Mon Unity Party & $\mathbf{5}$ & $\mathbf{1}$ & $<\mathbf{1}$ \\
\hline Kayah State Democratic Party & $\mathbf{5}$ & $\mathbf{1}$ & $<\mathbf{1}$ \\
\hline Kachin State People's Party & $\mathbf{1}$ & $<\mathbf{1}$ & $<\mathbf{1}$ \\
\hline Arakan Front Party & $\mathbf{1}$ & $<\mathbf{1}$ & $<\mathbf{1}$ \\
\hline Wa National Party & $\mathbf{1}$ & $<\mathbf{1}$ & $<\mathbf{1}$ \\
\hline Zomi Congress for Democracy & $\mathbf{1}$ & $<\mathbf{1}$ & $<\mathbf{1}$ \\
\hline Independents & $\mathbf{1}$ & $<\mathbf{1}$ & $<\mathbf{1}$ \\
\hline Military appointees & $\mathbf{1 6 6}$ & - & $\mathbf{2 5 * *}$ \\
\hline TOTAL & $\mathbf{6 4 2 *}$ & $\mathbf{1 0 0}$ & $\mathbf{1 0 0}$ \\
\hline
\end{tabular}

*Excluding cancelled (vacant) seats. **Not excluding cancelled (vacant) seats

\section{Ethnic political parties and the State and Region parliaments}

The 2020 elections also saw the NLD dominate in the States and Regions, and the party subsequently reiterated its commitment to achieving 'genuine federalism'. Myanmar is administratively divided into 14 States and Regions, each with their own constitutionally-derived set of powers. Regions are Bamar majority and have 
geographically-based names. States are formed in majority ethnic areas and named after the main ethnic nationality in the area (Figure 1). A variety of ethnic political parties claim to represent the interests of ethnic peoples, especially in the ethnic States.

Ethnic political parties and EAOs advocate for federal democracy as a way to end decades-long conflicts and ensure some level of self-determination for ethnic nationalities. It has long been argued that large and ethnically diverse countries like Myanmar need federalism in order to have a stable democracy. Currently, the 2008 Constitution lays out a federal system, but without 'genuine federalism'. For instance, the autonomy of States and Regions can be curtailed by the central government, and the Constitution renders constituent units subordinate to the central government.

The NLD won about 80 percent of elected State and Region parliament seats, or more than 60 percent of all seats, taking into account the military allocation. Ethnic political parties, which had been projected to make major gains in the 2020 election, in fact performed relatively poorly. Indeed, ethnic parties secured a strong presence in only two States (Shan State and Rakhine State), but no majorities. They won no seats in the Regions. The military's proxy party, the USDP, again generally performed poorly in State and Region parliaments.

\section{Figure 1: Map of Myanmar including approximate distribution of ethnic groups}




\section{MELBOURNE ASIA REVIEW}

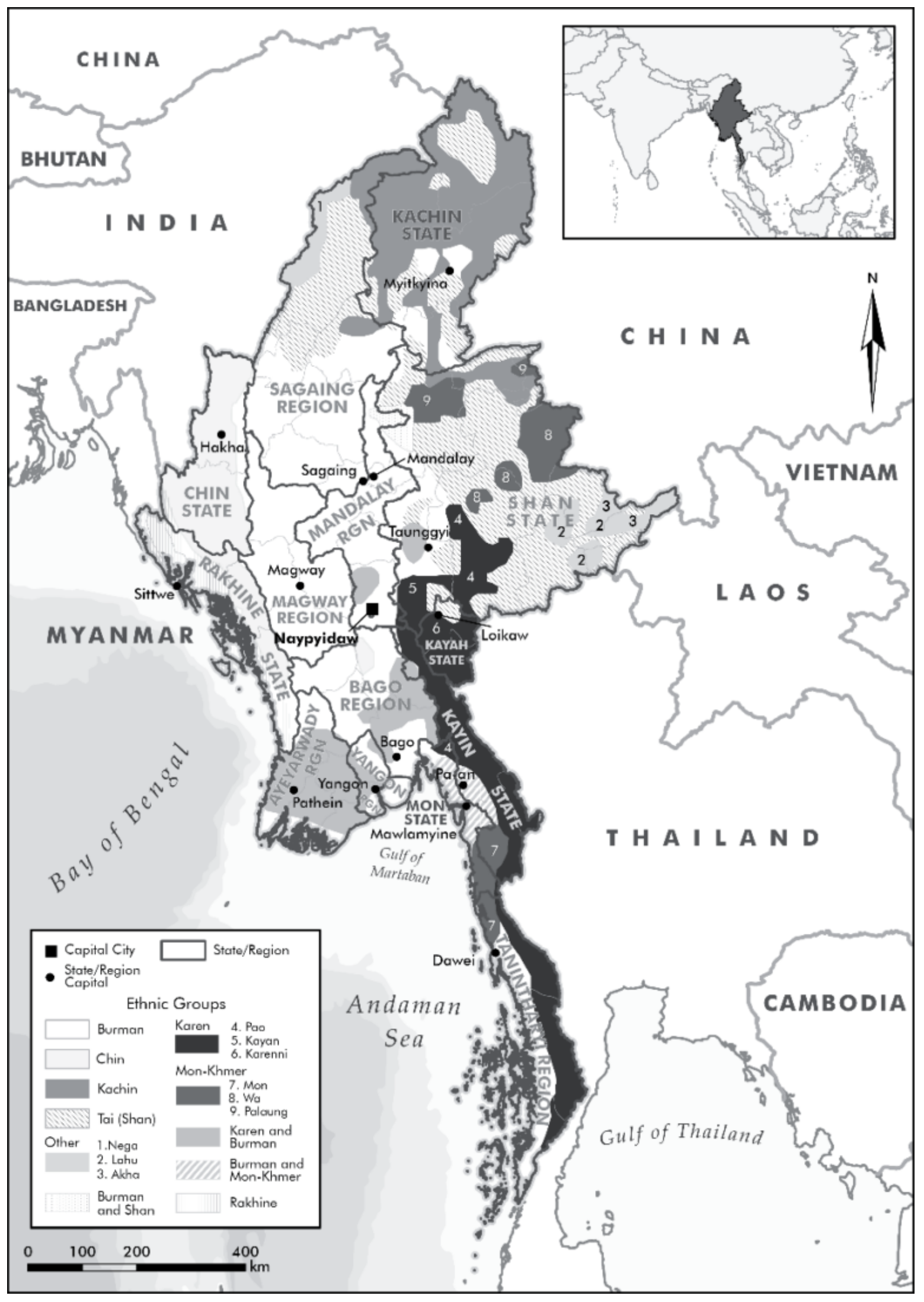


The authors acknowledge permission to use this map of Myanmar prepared by Kirke Narusk. The map uses ethnic distribution data based on Smith (1999).

The NLD did not create any alliances with other parties before the election. But it had afterwards raised talk of a national unity government, began courting ethnic parties and reiterated its commitment to federalism. A recent letter to the ethnic parties stated: 'As the ethnic parties' objectives and the NLD are the same the NLD would prioritize the ethnic's [sic] desires in the future...It is hoped that the ethnic parties would actively cooperate in realizing the democratic federalism' [translation from Burmese]. By some accounts, talks to this effect were progressing well.

Yet at the same time, barriers to federalism are built into the 2008 Constitution. One thing that makes Myanmar's system of government not genuinely federal is that the President of the Union appoints the Chief Ministers of the States and Regions. In fact, after the 2015 election, the NLD selected Chief Ministers from its own party against the wishes of ethnic parties in Shan and Rakhine States, which were the largest parties in those states. This time around, Aung San Suu Kyi said she herself would take a personal role in the appointment of Chief Ministers-something that would have further impeded progress towards the type of decentralisation of power which ethnic nationality groups in border areas continue to demand.

Despite these barriers, many in the military remain fearful of federalism, believing that it will lead to the disintegration of the state through secession of ethnic areas, and further weaken their control over populations and resource-rich areas in the country's peripheries. The risk of secession is a common concern in the region, and it is not entirely unfounded. Federalism can work to both reduce and increase the secession risk, depending on how it is designed and implemented. Some federal countries have broken up in the past. The NLD's courting of ethnic parties and statements of commitment to federalism, while not trusted by many amongst ethnic communities, may in turn have influenced the military's decision to seize control. 


\section{Party dominance and the electoral system}

The 2020 election and the military's response have highlighted two major barriers to democratisation in Myanmar. One lies in the military's control of powerful ministerial portfolios and the automatic allocation of parliamentary seats to the military. The second is the lack of an opposition and the risk of a one party system developing under the cult of personality of Aung San Suu Kyi. This is partly a result of the electoral system. One or both of these factors largely precluded Myanmar from being a genuine democracy, with or without a coup. And the latter was significant in prompting the military to seize power.

In fact, Myanmar effectively had a one-party system before the coup. A widely used measure for determining types of political party systems is the Effective Number of Political Parties. This is not a simple count of how many parties compete or win seats, but takes into account how influential they are. On this measure, Myanmar only had one and a half parties, which means it was a one-party system. Compared to democratic and ethnically diverse countries in the Asia region, like India, Nepal and Indonesia, Myanmar was an outlier (see Table 2).

Myanmar also had very disproportionate outcomes (see Table 2). That is, the proportion of seats won is much higher than the proportion of votes received. This is largely a result of the electoral system. Myanmar has a First-Past-the-Post, or winner takes all, electoral system. This can be contrasted to a Proportional Representation system, where seats are allocated in proportion to votes. First-Past-the-Post systems tends to exaggerate electoral majorities and lead to single party governments, whereas coalition governments are more likely under Proportional Representation.

Myanmar's electoral system itself was then instrumental in tipping the balance of power towards the NLD and away from the USDP (and other parties). The uneasy balance of power between the NLD and military leaders that had been maintained since the 2015 election was undermined. The coup tipped the scales back entirely in favour of the military. 


\section{Table 2: Measures of political parties and electoral disproportionality in eight countries}

\begin{tabular}{|l|r|l|l|}
\hline & $\begin{array}{l}\text { Effective Number of } \\
\text { Parliamentary Parties } \\
\text { (ENPP) 10-year } \\
\text { average (2008-17) }\end{array}$ & $\begin{array}{l}\text { Disproportionality } \\
\text { (Gallagher Index) 10- } \\
\text { year average (2008-17) }\end{array}$ & $\begin{array}{l}\text { Party system } \\
\text { (fragmentation)* }\end{array}$ \\
\hline India & 4.49 & 18.35 & Multiparty \\
\hline Indonesia & 7.03 & 6.40 & Multiparty \\
\hline Malaysia & 4.65 & 8.06 & Multiparty** \\
\hline Myanmar & 1.56 & 20.25 & One-party \\
\hline Nepal & 4.15 & 7.61 & $\begin{array}{l}\text { Multiparty with } \\
\text { dominant party }\end{array}$ \\
\hline Pakistan & 4.12 & 10.48 & $\begin{array}{l}\text { Multiparty with } \\
\text { dominant party }\end{array}$ \\
\hline Philippines & 5.34 & 5.30 & Multiparty \\
\hline Sri Lanka & 2.32 & 3.49 & Two-and-half party \\
\hline
\end{tabular}

* Based on the ENPP whereby one-party system if $>1.75$; two-party 1.76>2.25; two-and-a-half party systems $2.26>3$; multiparty systems with a dominant party $3.01>4.25$; and, multiparty systems $<4.25+$.

** Using parties rather than alliances. Source: authors' calculations adapted from Breen (2020).

\section{Cancelled seats, allegations of fraud and the military coup}

On February 1 2021, the military, invoking Article 417 of the Constitution, arrested NLD leaders and officials, and declared a one-year state of emergency. They claimed 
that the alleged electoral fraud amounted to 'attempts to take over the sovereignty of the Union by... wrongful forcible means' (417(c)). Under Article 418, all the members of institutions of the state appointed by the parliaments were 'terminated from duty', including the Union Election Commission. The military appointed former General Myint Swe as President and transferred all executive, legislative and judicial power to the Commander-in-Chief Min Aung Hlaing. It said it would investigate the alleged electoral fraud and hold a new election within one year.

The military had initially raised concerns about the Union Election Commission before the election and said it would hold the NLD responsible. The Commission, which was appointed by the NLD, had cancelled elections for 22 seats-all in ethnic areas and none held by the NLD. In total, more than one million people were unable to vote in Myanmar's elections, with voting cancelled in large parts of Shan and Rakhine States, as well as parts of Kachin, Chin and Mon States and Bago Region due to alleged security concerns linked with ongoing civil conflict. A suspicious observer might take this as a deliberate ploy to ensure that the NLD maintain the balance of power and was not obliged to do deals with ethnic parties, the USDP or the military.

Significantly, the election outcomes point to ongoing discomfort amongst Myanmar's population over the role of the military, and USDP, in politics. Many voters including those in ethnic areas took to the polls with the attitude of 'we vote for the NLD because we don't want the military'. Votes ostensibly for the NLD in the 2020 election should in many cases instead be interpreted as votes against the military. Similarly, the participation of many individuals and groups from ethnic nationality groups in the growing movements of protest that have been taking place across the country in reaction to the coup should not, in many cases, be read as support for the NLD or Aung Sun Suu Kyi but instead as resistance against the resumption of military rule.

Now, people across the country-whether in Bamar-majority central areas or in the ethnic States-are angry. Despite the harsh crackdowns of the past, individuals have 
taken to the streets in the largest protests the country has seen since the so-called 'Saffron Revolution' of 2007. Forms of civil disobedience have spread, with health, education and other essential workers refusing to work. People are being urged to boycott the military's business interests, such as the popular Myanmar Beer. At the time of publication, tensions are high and fears of a violent crackdown are growing.

At the international level, there has been considerable condemnation of the coup, and the US among others has announced it will impose new sanctions against military figures. The question is whether China will support the new regime. China is investing heavily in development in Myanmar, through the Belt and Road Initiative, and a slowdown would impact the economic aspirations of the military.

\section{Impacts for federalism, peace and self- determination of ethnic nationalities}

The results of the 2020 election did not bode particularly well for ethnic nationalities who have been struggling for decades for some level of autonomy from the Myanmar state. Renewed NLD dominance in State parliaments was likely, for example, to reinforce local grievances, since these decentralised structures were meant to give some (albeit limited) autonomy to ethnic nationalities.

More generally, Myanmar's electoral systems and politics were not conducive to addressing the aspirations of ethnic communities. But the coup will likely make things even worse for ethnic nationality groups, thwarting their aspirations for federalism and undermining a peace process that had already suffered major setbacks.

Myanmar's $21^{\text {st }}$ Century Panglong Conference (Union Peace Conference) was meant to be the process by which key actors would determine the principles and details of federal and democratic constitutional reform. It includes representatives of political parties, the military, civil society and Ethnic Armed Organisations (EAOs), but not 
all. After commencing in 2016, hopes were high. But since that first conference, only three more meetings have been held, the latest in July 2020. And while general principles have been established, there had been little detail and no agreement on the most fundamental issues prior to the recent election. Given views amongst the military in relation to federalism, it is not likely that significant progress will be made.

Meanwhile, the so-called Nationwide Ceasefire Agreement (NCA)-established in 2015 by the Government and eight EAOs-was flailing even before the coup. For one, the NCA did not include some of the largest and most influential EAOs in the country, and many in Myanmar felt that it had failed to deliver any real solutions. And with fighting having resumed in Kayin State in late 2020 due to broken government ceasefire promises and what the Karen National Liberation Army (which had signed the NCA in 2015) sees as state military expansionism in its territory, Myanmar's peace process was already seen by many as being at death's door.

Since seizing power, the military has said that it will still progress the peace process. Some ethnic actors, including the Arakan National Party, have chosen to join the military government. But the military's approach to the peace process may otherwise translate into a crackdown on EAOs that do not toe the line. Myanmar military operations in Kayin State have continued, resulting in violence against and displacement of civilian populations. With Karen National Party and Karen National Democratic Party leaders having rejected an offer of government positions by military leaders, it is possible that tensions will continue to escalate in other areas of Kayin State as well. More generally, the coup will surely exacerbate the vulnerability of ethnic communities throughout the country.

The coup is particularly bad news for Rohingya people, inside and outside the country. Some 600,000 Rohingya people are still in Myanmar, and must fear what the military has in store for them, given the tragic events of 2017. It also undermines any hopes that Rohingya refugees may have harboured about returning to the country. While the disenfranchisement of Rohingya communities during the 2020 
election was the subject of much international critique, many Myanmar citizens support the view that the Rohingya are 'illegal Bengali migrants'-their exclusion therefore not being a cause for alarm. The military may well capitalise on this sentiment in the current conditions.

\section{A concerning future}

Myanmar's 2020 election had been claimed to consolidate the country's transition to democracy. But instead it led to its collapse-something which does not bode well for ethnic nationalities and a peace process that had already been marred by numerous setbacks and renewed violence.

The military has said that during its 'caretaker' period, it will expedite the peace process. How it intends to do this remains to be seen. But if its actions in reigniting conflict in Kayin State, for example, are anything to go by, then there is reason to be seriously concerned.

The NLD had previously spent much effort while in government appeasing the military, perhaps fearful of a democratic reversion. These fears have now become reality. The military's actions are a response not so much to allegations of electoral fraud, but to the dominance of the NLD-something that was driven in part at least by popular fear of the military as well as the electoral system itself. The coup in turn reveals the two big democratic problems that were being faced-military autonomy and political influence, and the electoral dominance of the NLD.

Although personal ambitions and vested interests will always play a role, the system itself enabled and led to this coup. The reinstatement of democratic institutions in Myanmar needs to be accompanied, or at least followed, by constitutional change to end military control over government and to reform the electoral system to prevent a future consolidation of power in one body. In addition, genuine federalism remains a necessary response to the demands of ethnic nationalities and a future bulwark against the re-emergence of tyranny. The challenges to democracy are the same 
ones that existed before the coup, though they are now much greater and more pressing.

[1] The Union Parliament is made up of the Upper House of Nationalities (Amyotha Hluttaw) and Lower House of Representatives (Pyithu Hluttaw).

Authors: Dr Michael Breen and Dr Anne Décobert

Image: Unidentified group of Myanmar soldiers. Credit: anonymous605936/Shutterstock. 